\title{
SISTEM PAKAR UNTUK MENDIAGNOSA PENYAKIT INFEKSI TBC PARU
}

\author{
Rifki Indra Perwira ${ }^{(1)}$, Anifudin Aziz ${ }^{(2)}$ \\ (1) Teknik Informatika \\ Universitas Pembangunan Nasional "Veteran" Yogyakarta \\ Tambakbayan 2 Babarsari, Yogyakarta. \\ ${ }^{(2)}$ IImu Komputer \\ Universitas Gadjah Mada Yogyakarta \\ Sekip Utara Bls, Yogyakarta.
}

\begin{abstract}
Expert system is made to transfer the expert knowledge into the system, so it hopefully can give solution to problem. "Expert system for diagnosis of infection TBC lung disease" is an alternative for the various expert system that can be used to overcome the problem. The aim of designing expert system is for diagnosis of infection TBC lung disease, should that users can diagnose towards this illnes based on symptoms put into this system. Development of expert system uses knowledge base stored in database using Paradox, rule based with forward chaining method.The result of consultation with the system indicate that this system can determine disease and suggestion based on symptoms inputed by user.
\end{abstract}

\section{Keyword : Expert System, Forward Chaining, Knowledge Base}

Sistem Pakar dibuat untuk memindahkan pengetahuan yang dimiliki oleh pakar ke dalam suatu sistem, sehingga diharapkan dapat memberikan jawaban atas suatu permasalahan. "Sistem Pakar untuk mendiagnosa penyakit infeksi TBC paru" adalah salah satu alternatif dari berbagai macam sistem pakar yang dapat dipakai untuk mengatasi permasalahan yang dihadapi. Tujuan rancang bangun sistem pakar ini adalah agar pemakai dapat melakukan diagnosa terhadap penyakit ini berdasarkan gejala-gejala yang dimasukkan kedalam sistem. Pembangunan sistem pakar ini menggunakan basis pengetahuan yang disimpan dalam basis data menggunaka n Paradox, berbasis aturan dengan metode pelacakan kedepan (runut maju). Hasil yang diperoleh dari konsultasi dengan sistem ini menunjukkan bahwa sistem mampu menentukan penyakit dan saran berdasarkan gejala yang diinputkan oleh pemakai.

Kata kunci : Sistem Pakar, Pelacakan Kedepan, Basis Pengetahuan.

\section{PENDAHULUAN}

\section{Latar Belakang}

Pada mulanya komputer diciptakan sebagai mesin hitung kemudian berkembang pesat sehingga dapat digunakan untuk mengolah data sebagai informasi pengambilan keputusan. Keberadan komputer dewasa ini banyak dimanfaatkan oleh berbagai bidang untuk meningkatkan kinerja yang dapat memberikan informasi yang lebih akurat. Pemrograman sistem pakar merupakan salah satu perangkat lunak yang digunakan dalam bidang riset ilmu pengetahuan dan teknologi, penerapan dasar ilmu yang dapat digunakan untuk menganalisa suatu fakta penelitian.

Sistem pakar merupakan cabang dari Artificial intelligent (Al). Implementasi sistem pakar banyak digunakan untuk kepentingan komersial karena sistem pakar dipandang sebagai cara penyimpanan pengetahuan pakar dalam bidang tertentu ke dalam program sehingga komputer dapat memberikan keputusan dan melakukan penalaran secara cerdas. Bidang kesehatan merupakan bagian dari bidang-bidang lain yang memanfaatkan teknologi komputer, salah satunya yang digunakan untuk mendiagnosa penyakit infeksi TBC paru.

Penyakit ini merupakan salah satu penyakit yang paling ditakuti. Umumnya penderita dapat dilihat secara fisik karena gejala-gejala yang mudah dikenali. Dengan mempertimbangkan 
kenyataan-kenyataan di lingkungan masalah kesehatan masyarakat yang masih kurang mendapat perhatian terutama masalah penyakit infeksi TBC paru yang memprihatinkan bagi pemerintah Indonesia maupun dunia. Kenyataan dan kondisi yang ada saat ini di lingkungan mengenai penyakit infeksi tuberkulosis paru antara lain (Hisyam, 2005) :

a. Tiap tahun jumlah manusia meninggal akibat infeksi tuberkulosis ternyata lebih besar dari tahun sebelumnya, tiap tahun 2-3 juta penduduk meninggal akibat TBC paru.

b. Paling sedikit 1 orang akan terinfeksi tiap detik.

c. Keterlambatan pengobatan pada seseorang penderita aktif dapat mengakibatkan menular pada orang lain.

d. Penyakit ini mudah menular dan menyebar melalui udara.

e. Kematian akibat infeksi ini biasanya terjadi secara bertahap

Sistem pakar yang digunakan untuk mendiagnosa penyakit infeksi TBC paru diharapkan dapat mengurangi angka kematian pada manusia karena diagnosa yang dilakukan tidak membutuhkan waktu lama dan tidak harus menunggu dokter. Seringkali kematian disebabkan karena penanganan awal yang lambat. Untuk alasan tersebut, maka penelitian ini mengangkat persoalan menjadi Sistem Pakar Untuk Mendiagnosa Penyakit Infeksi TBC Paru.

\section{Perumusan Masalah}

Berdasarkan uraian latar belakang diatas, maka penulisan Tugas Akhir ini dapat dirumuskan sebagai berikut:

1. Bagaimana membangun sebuah sistem pakar untuk mendiagnosa penyakit infeksi TBC paru yang sederhana sehingga dapat membantu mengetahui penyakit yang diderita pasien.

\section{Tujuan}

Penelitian ini bertujuan untuk :

1. Melakukan rancang bangun Sistem Pakar Untuk Mendiagnosa Penyakit Infeksi TBC Paru

2. Merancang sistem pakar yang mampu memberikan saran berdasarkan gejala yang diinputkan user.

\section{TINJAUAN PUSTAKA}

Berdasarkan penelitian sebelumnya, telah dirancang Sistem Pakar yang dibuat oleh Asiyah (2005), referensi sistem pakar di bidang kesehatan gigi. Sistem ini menggunakan dialog interaktif juga antara pemakai dengan sistem pakar, yaitu sistem untuk mendiagnosa penyakit gigi pasien. Gejala-gejala penyakit gigi yang dialami pasien sebagai bahan masukan, kemudian mesin inferensi akan mengolah selayaknya pakar sehingga akan menghasilkan suatu kesimpulan penyakit gigi apa yang diderita oleh pasien tersebut, selain itu sistem ini juga akan memberikan konsultasi dan saran bagi pasien untuk melakukan perawatan gigi.

Sistem pakar di bidang kesehatan yang lain yaitu dengan judul Sistem Pakar Untuk Membantu Diagnosa Gangguan Pernafasan Pada Hewan Ternak (Beni, 2006). Sistem ini didapat dari wawancara dengan ahli ternak atau mantri hewan, membaca buku, jurnal dan hasil penelitian terdahulu. Hasil diagnosa ini untuk mendiagnosa gangguan pernafasan pada sistem pernafasan ternak berdasarkan gejala-gejala yang dimasukkan ke dalam sistem. Penelusuran yang digunakan dalam sistem ini adalah backward chaining. Sistem ini telah berjalan baik dan memberikan fasilitas saran bagi ternak serta fasilitas untuk menambah pengetahuan dengan tampilan yang user friendly.

Sistem pakar penentuan bibit tebu dari ketersediaan lahan perkebunan rayon bantul pabrik gula madukismo yogyakarta (Dian, 2006). Sistem Pakar ini digunakan untuk menentukan jenis bibit yang sesuai dengan keadaan lahan. Mesin inferensi penelitian ini menggunakan forward chaining dan penelusuran breadth first search. Hasil dari penelitian ini adalah dapat menentukan jenis bibit tebu yang sesuai dengan kondisi lahan sehingga diharapkan pertumbuhan tebu dapat optimal.

\subsection{Sistem Pakar}

Sistem pakar diambil dari istilah knowledge base expert system yang merupakan hasil dari proses knowledge engineering. Sistem pakar pertama kali dikembangkan oleh komunitas artificial intelligent pada pertengahan tahun 1960. Sistem pakar yang muncul pertama kali adalah General Purpose Problem Solver (GPS) yang dikembangkan oleh Newel dan Simon (Giarratano dan Rilley, 2004). 
Sistem pakar adalah sistem yang berusaha mengadopsi pengetahuan manusia (Pakar) ke komputer, sehingga komputer dapat menyelesaikan permasalahan tersebut layaknya seorang pakar (Kusumadewi, 2003). Sampai saat ini sudah banyak sistem pakar yang dibuat. Kemampuannya untuk memberikan keputusan seperti seorang pakar di dalam bidang tertentu merupakan salah satu hal yang diperlukan oleh manusia dalam berbagai aspek kehidupan.

Sistem pakar dibuat pada domain pengetahuan tertentu untuk suatu kepakaran tertentu yang mendekati kemampuan manusia di salah satu bidang. Sistem pakar mencoba mencari solusi yang memuaskan sebagaimana yang dilakukan seorang pakar.

Ada beberapa pertimbangan menggunakan sistem pakar. Dibawah ini sebagian dari pertimbangan yang utama :

a. Membantu melestarikan cagar alam pengetahuan dan keahlian pakar.

b. Jika keahlian adalah langka, mahal atau tak terbatas.

c. Mudah digunakan walaupun bukan seorang ahli.

\subsection{Arsitektur Sistem Pakar}

Sistem pakar disusun oleh 2 bagian utama yaitu lingkungan pengembang dan lingkungan konsultasi (Turban, 2005). Lingkungan pengembang sistem pakar digunakan untuk memasukkan pengetahuan ke dalam lingkungan sistem pakar, sedangkan lingkungan konsultasi digunakan oleh pengguna yang bukan pakar guna memperoleh pengetahuan pakar. Komponen sistem pakar dapat dilihat dalam gambar 1.

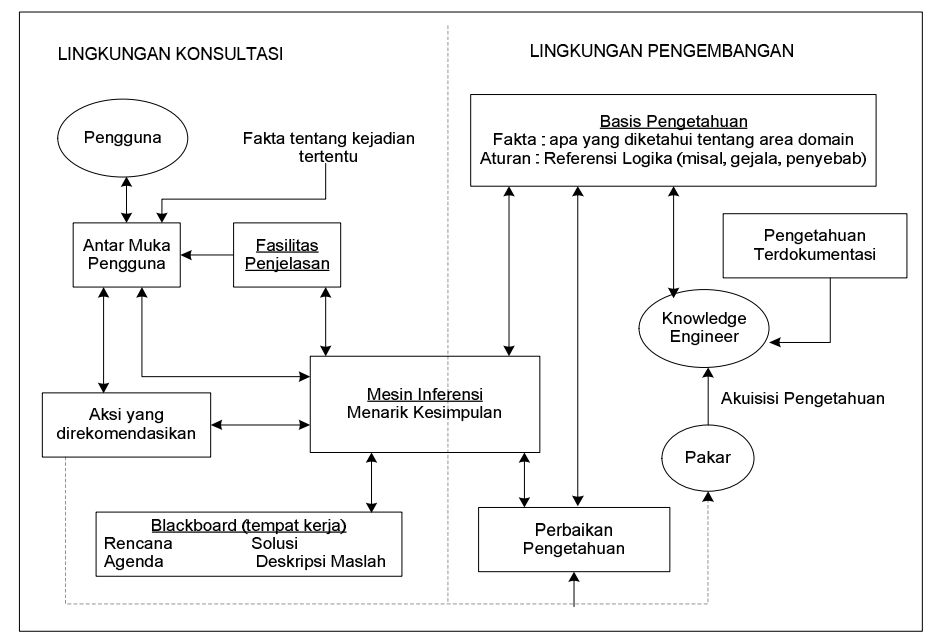

Gambar 1. Arsitektur sistem pakar (Turban, 2005)

\subsection{Mesin Inferensi}

Mesin inferensi adalah bagian yang mengandung mekanisme fungsi berfikir dan pola-pola penalaran sistem yang digunakan oleh seorang pakar. Mekanisme ini menganalisa suatu masalah tertentu dan selanjutnya akan mencari jawaban atau kesimpulan. Mesin inferensi memiliki tiga elemen pokok (Turban, 2005) yaitu :

1. Penerjemah (Interpreter), yang menjalankan pilihan jenis-jenis agenda dengan menerapkan kaidah basis pengetahuan yang ada.

2. Pengaturan (Scheduler), yang mengatur control atas agenda. Penalaran mempengaruhi kaidah inferensi dalam jenis prioritas yang jelas atau kriteria lain di dalam agenda.

3. Kemampuan Penyelesaian (Consistency Enforcer), yang mencoba untuk menjaga ketepatan representasi dari penyelesaian yang muncul. Bagian ini akan berusaha memelihara kekonsistenan dalam merepresentasikan solusi yang bersifat darurat.

Mesin inferensi memulai pelacakan dengan mencocokkan kaidah-kaidah dalam pengetahuan dengan fakta-fakta yang ada dalam basis data. Adapun teknik pelacakan (Kusumadewi, 2003) yaitu :

\section{a) Forward Chaining}

Pencocokan fakta atau pernyataan dimulai dari bagian kiri (IF). Dengan kata lain penalaran dimulai dengan fakta yang ada pada bagian premis aturan IF [fakta] THEN [kesimpulan]. Untuk menguji kebenaran hipotesis, dari fakta-fakta tersebut selanjutnya akan ditentukan kesimpulan 
yang terletak pada sebelah kanan aturan IF [fakta] THEN [kesimpulan]. Teknik pelacakan forward chaining dapat dilihat pada Gambar 2.

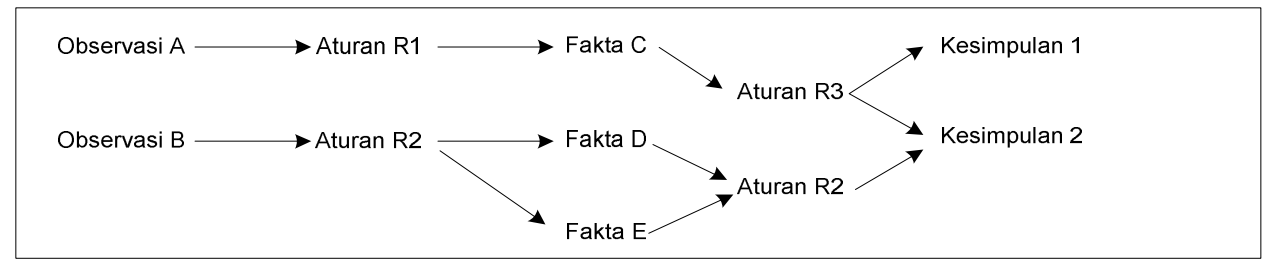

Gambar 2. Forward chaining

\section{b) Backward Chaining}

Pencocokan fakta atau pernyataan dimulai dari bagian kanan (THEN). Dalam pendekatan ini pelacakan dimulai dari informasi masukan yaitu data tujuan dari aturan IF [fakta] THEN [tujuan], kemudian dicari fakta dari aturan-aturan yang memiliki tujuan tersebut sebagai kesimpulannya. Proses berlanjut sampai semua kemungkinan ditemukan. Teknik pelacakan forward chaining dapat dilihat pada Gambar 3.

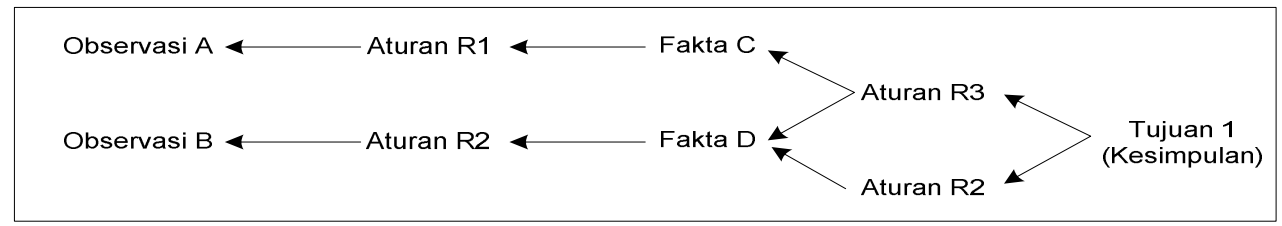

Gambar 3. Backward chaining

Kedua metode inferensi tersebut dipengaruhi oleh tiga macam penelusuran, yaitu Depth-first search, Breadth-first search dan Best-first search.

a. Depth-first search, melakukan penelusuran kaidah secara mendalam dari simpul akar bergerak menurun ke tingkat dalam yang berurutan. Keuntungan menggunakan metode ini adalah membutuhkan memory yang relatif kecil karena hanya menyimpan node yang aktif saja. Namun ada pula kekurangannya yaitu memungkinkan tidak ditemukan solusi yang diharapkan serta hanya akan mendapat 1 solusi (gagal atau ditemukan) pada setiap pencariannya.

b. Breadth-first search, melakukan penelusuran kaidah bergerak dari simpul akar, simpul yang ada pada setiap tingkat diuji sebelum pindah ke tingkat selanjutnya. Keuntungan menggunakan metode ini adalah tidak akan menemui jalan buntu karena hampir semua node ditelusuri akibatnya solusi yang ditemukan bisa lebih dari satu. Namun kekurangannya membutuhkan memori yang cukup banyak serta membutuhkan waktu yang cukup lama karena menguji semua level.

C. Best-first search, penelusuran ini bekerja berdasarkan kombinasi kedua metode tersebut. Berikut ini Gambar 4 dan Gambar 5 adalah diagram alir untuk Depth-first search dan Breadthfirst search.

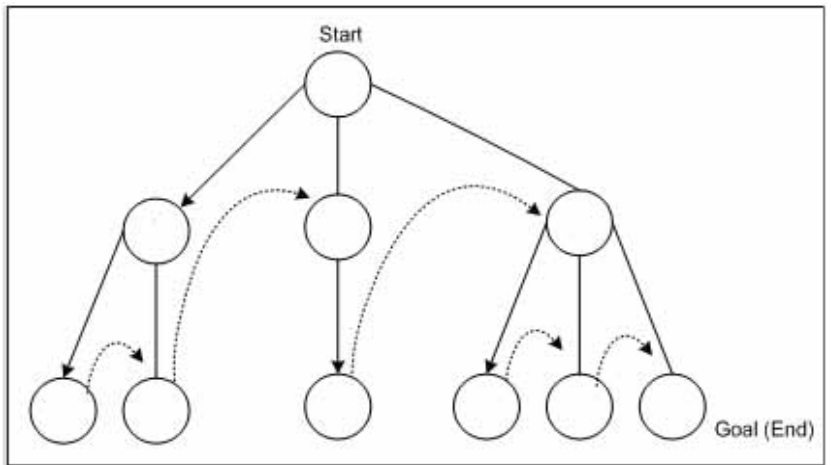

Gambar 4. Diagram Alir Teknik Penelusuran Depth-first search 


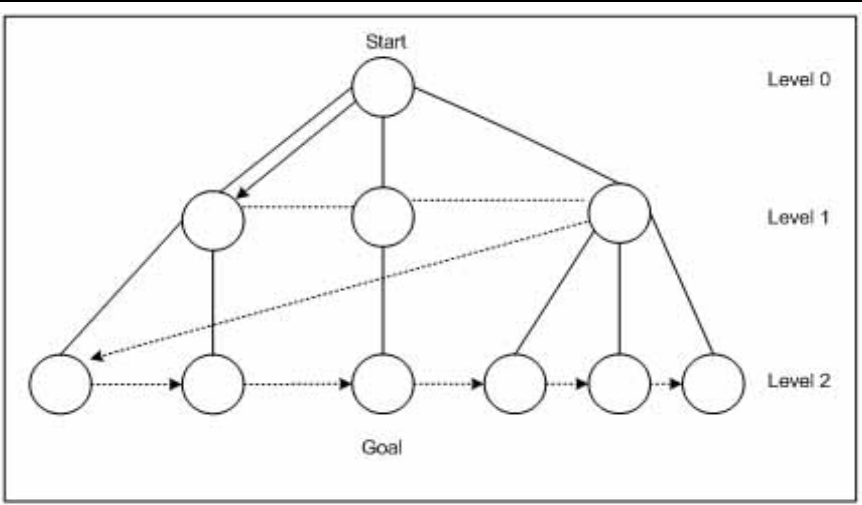

Gambar 5. Diagram Alir Teknik Penelusuran Breadth-first search

\subsection{Representasi Pengetahuan}

Beberapa model dari representasi pengetahuan (Kusumadewi, 2003) adalah :

\section{a. Representasi Logika}

Input untuk proses logika disebut premise atau fact, fakta digunakan dalam proses logika untuk membuat output yang merupakan kesimpulan (Conclusion) disebut inferensi kesimpulan. Proses-proses logika yang dilakukan berdasarkan hubungan-hubungan logika $A N D, O R$, NOT, Implies, Equivalent, dimana kriteria kebenaran hasil proses yang didapat adalah benar (True) dan salah (False).

Ada dua teknik dalam komputasi logika :

\section{Logika Proposisional}

Logika proposisional adalah logika yang menangani kalimat deklaratif atau pernyataan yang bernilai benar atau salah. Logika proposisional hanya dapat bekerja terhadap pernyataan yang lengkap dan tidak dapat menganalisa struktur internal sebuah pernyataan, sehingga untuk menganalisa kasus yang lebih umum dikembangkan logika predikat yang dapat menganalisis structural internal kalimat (Giarratano dan Riley 2004).

Contoh : Bujur sangkar mempunyai 4 sisi.

Kalimat tersebut merupakan logika proporsional karena mengandung pernyataan yang mempunyai nilai kebenaran.

\section{Logika Predikat}

Logika predikat adalah memberikan kebebasan untuk memecah statement menjadi beberapa bagian misalnya nama objek, sifat-sifat dari objek atau beberapa yang menyangkut objek. Logika predikat menganalisa struktur internal suatu kalimat yang difokuskan pada penggunaan quantifier, seperti "semua", "beberapa", dan "tidak ada". Quantifier ini menjadi penting karena dengan quantifier inilah kata yang lain dapat diukur, sehingga kalimat yang dihasilkan lebih eksak.

Contoh : Semua persegi panjang adalah poligon.

\section{b. Jaringan Semantik (Semantic Networks)}

Representasi jaringan semantik merupakan gambaran grafis dari pengetahuan yang memperlihatkan hubungan hirarki dari objek-objek. Komponen dasar untuk merepresentasi pengetahuan dalam bentuk jaringan semantik adalah simpul (Node) dan penghubung (Link). Objek direpresentasikan oleh simpul, hubungan antar objek-objek dinyatakan oleh penghubung yang diberi label untuk menyatakan hubungan yang direpresentasikan .

\section{c. Kaidah Produksi (Production Rules)}

Kaidah produksi merupakan representasi yang tersusun atas kaidah-kaidah yang mengikuti pola bentuk kondisi-aksi yaitu pasangan : "IF Kondisi (Premise atau antecedent), THEN Aksi (hasil, atau kesimpulan, atau konsekuensi)".

Kaidah dapat diklasifikasikan menjadi dua yaitu Kaidah Derajat Pertama (First Order Rule) dan kaidah Meta (Meta Rule) (Giarratano dan Riley, 2004). Kaidah derajat pertama adalah kaidah sederhana yang terdiri dari antesenden dan konsekuensi. Kaidah meta adalah yang antesenden dan konsekuensinya mengandung informasi tentang kaidah yang lain.

\section{d. Bingkai (Frames)}

Bingkai merupakan struktur data yang memasukan semua pengetahuan tentang objek tertentu. Pengetahuan diatur di dalam struktur hirarki khusus. Masing-masing bingkai menggambarkan 
suatu objek. Bingkai mempunyai dua elemen dasar yaitu slots dan facets. Slot adalah himpunan dari atribut yang menggambarkan objek yang dinyatakan oleh bingkai. Masingmasing slot mengandung satu atau lebih facets (subslot) yang menggambarkan beberapa pengetahuan atau prosedur tentang atribut di dalam slot.

\section{e. Pohon Keputusan}

Pohon merupakan struktur penggambaran secara hirarkis. Struktur pohon terdiri dari node-node yang menunjukkan objek, dan arc (busur) yang menunjukkan hubungan antar objek. Representasi pohon ini banyak digunakan untuk menggambarkan suatu masalah dalam ruang keadaan sehingga menghindari proses pelacakan yang berulang. Teknik yang sering digunakan adalah Pohon AND/OR dimana teknik ini mampu mereduksi struktur pohon yang bertingkat menjadi hanya beberapa tingkat saja.

\section{METODE PENELITIAN}

\section{Pengumpulan Data}

Tahapan Pengumpulan data dengan pakar pada umunya meliputi hal-hal sebagai berikut :

a. Diskusi domain permasalahan pada infeksi TBC paru.

Diskusi ini dilakukan di awal pertemuan dengan para pakar, dimana akan mendapatkan penjelasan apa-apa saja yang terkait dengan gejala, penyakit dan saran bagi penderita.

b. Wawancara, tanya jawab semua hal yang berkenaan dengan domain mendiagnosa penyakit yang tepat. Domain-domain tersebut adalah proses penentuan gejala dan penyakit hingga saran/terapinya.

c. Studi literatur, yaitu studi penelitian-penelitian sebelumnya yang pernah dilakukan oleh para peneliti dengan domain yang hampir mirip.

\section{Representasi Pengetahuan}

Pengetahuan yang diperoleh harus direpresentasikan dalam format yang dapat dipahami oleh manusia dan dapat dieksekusi pada komputer.

Tujuan Representasi Pengetahuan adalah membuat suatu struktur yang dapat digunakan untuk membantu pengkodean pengetahuan ke dalam suatu program. Intinya, pengetahuan direpresentasikan ke dalam format tertentu dan akan dihimpun ke dalam suatu basis pengetahuan.

Ada banyak cara yang berbeda untuk merepresentasikan pengetahuan, salah satunya adalah dengan aturan produksi, agar dapat ditangani oleh mesin inferensi sebagai "otak" dari sistem pakar ini. Langkah-langkah yang dilakukan adalah :

1. Membuat Tabel Keputusan.

2. Membuat Pohon Keputusan.

3. Mengkonversi pohon keputusan menjadi kaidah produksi.

\section{Tabel Keputusan}

Pengetahuan relasi dapat direpresentasikan dalam format spreadsheet menggunakan kolom dan baris. Tabel keputusan untuk atribut fakta dan kesimpulan dari pengetahuan yang telah diakuisisi Adapun tabel keputusan penyakit infeksi TBC paru berdasarkan gejala-gejala seperti yang terlihat pada Tabel 1.

Nama penyakit :

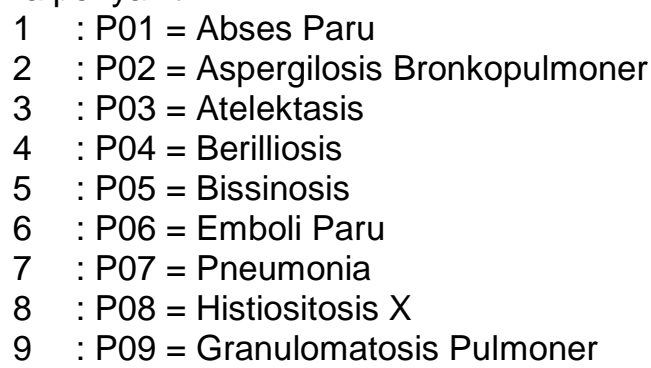


Tabel 1. Tabel keputusan

\begin{tabular}{|c|c|c|c|c|c|c|c|c|c|c|}
\hline No & Gejala / Kode Penyakit & P01 & P02 & P03 & P04 & P05 & P06 & P07 & P08 & P09 \\
\hline G001 & Batuk berdahak kadang disertai darah & * & * & & & & & & & \\
\hline G002 & Batuk berdahak disertai bau busuk & * & & & & & & & & \\
\hline G003 & Nyeri dada ketika bernafas & * & & & & & & & & \\
\hline G004 & Sering merasa kelelahan & * & & & & & & & & \\
\hline G005 & Nafsu makan berkurang & * & & & & & & & & \\
\hline G006 & Berat badan turun secara perlahan & * & & & & & & & & \\
\hline G007 & Sesak nafas berat (asma yang memburuk) & & * & & & & & & & \\
\hline G008 & Mengi/bengek & & * & & & & & & & \\
\hline G009 & Demam & & * & & & & & & & \\
\hline G010 & Sesak nafas ringan (seperti asma) & & & * & * & * & & & & \\
\hline G011 & Mengalami gangguan pernafasan & & & * & & & & & & \\
\hline G012 & Nyeri dada & & & * & & & & & & \\
\hline G013 & Batuk kering & & & * & & & & & & \\
\hline G014 & Berat badan turun secara drastis & & & & * & & & & & \\
\hline G015 & Badan terasa lemas & & & & * & & & & & \\
\hline G016 & Ada riwayat pemaparan debu & & & & & * & & & & \\
\hline G017 & Kondisi memburuk jika berada di tempat kerja & & & & & * & & & & \\
\hline G018 & Kondisi membaik jika jauh dari tempat kerja & & & & & * & & & & \\
\hline G019 & Dada terasa sesak & & & & & * & & & & \\
\hline G020 & Batuk pendek pendek & & & & & * & & & & \\
\hline G021 & Pernafasan cepat & & & & & & * & * & & \\
\hline G022 & Denyut jantung cepat & & & & & & * & & & \\
\hline G023 & Keluar keringat (berkeringat) & & & & & & * & & & \\
\hline G024 & Pusing & & & & & & * & & & \\
\hline G025 & Batuk berdahak kadang dahak disertai nanah & & & & & & & * & & \\
\hline G026 & Kadang disertai rasa mual dan muntah & & & & & & & * & & \\
\hline G027 & Badan menggigil & & & & & & & * & & \\
\hline G028 & Volume air seni meningkat & & & & & & & & * & \\
\hline G029 & Kadang disertai nyeri tulang & & & & & & & & * & \\
\hline G030 & Sering merasa haus walaupun banyak minum & & & & & & & & * & \\
\hline G031 & Mudah merasa lelah & & & & & & & & & * \\
\hline G032 & Tidak enak badan (malaise) & & & & & & & & & * \\
\hline G033 & Terjadi pendarahan di hidung & & & & & & & & & * \\
\hline G034 & Ada Luka disekitas hidung & & & & & & & & & * \\
\hline
\end{tabular}

\section{Pohon Keputusan}

Pohon keputusan dibuat untuk memudahkan pembangun sistem dalam merepresentasikan pengetahuan ke dalam bahasa yang dapat dimengerti oleh komputer, dalam hal ini adalah mesin inferensi. Gambar 6 dan Gambar 7 di bawah ini menggambarkan bagan pohon keputusan dari pengetahuan-pengetahuan yang telah diakuisisi :

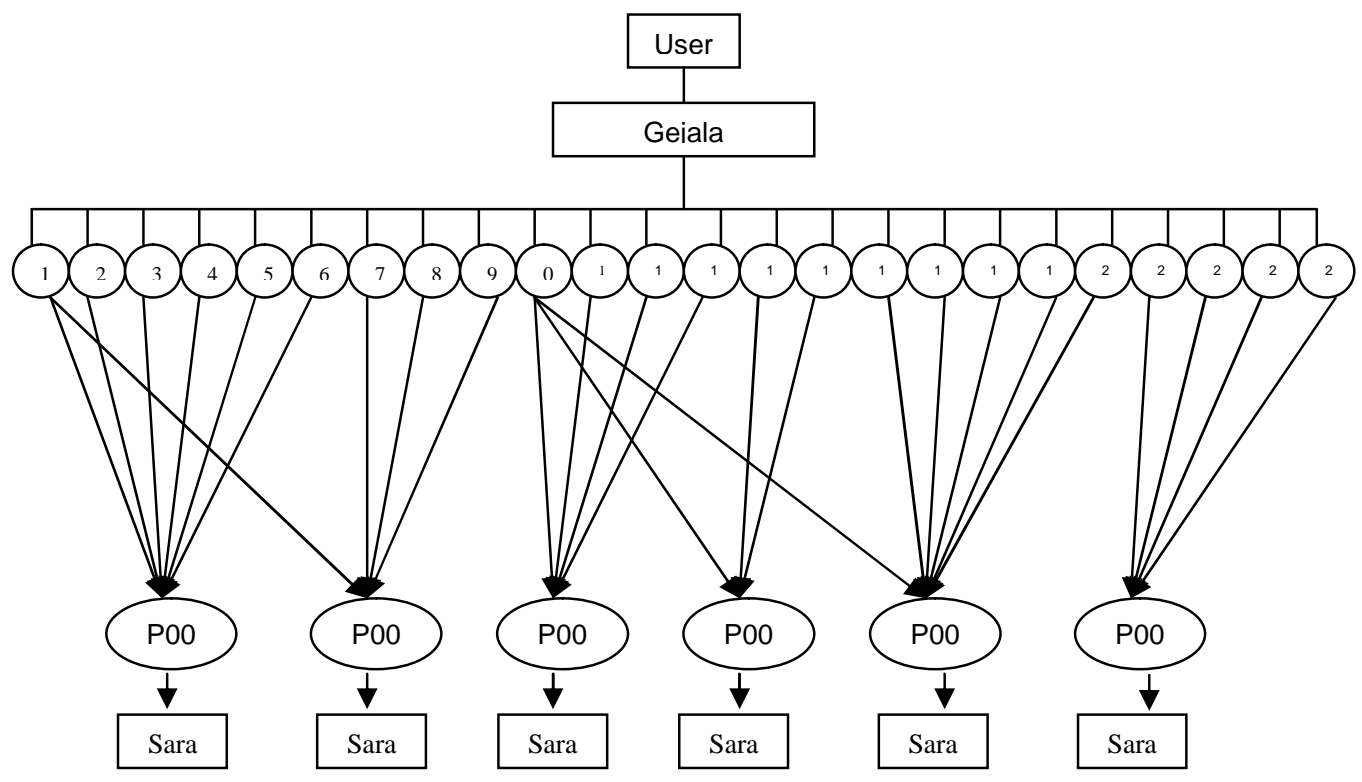

Gambar 6. Pohon Keputusan 


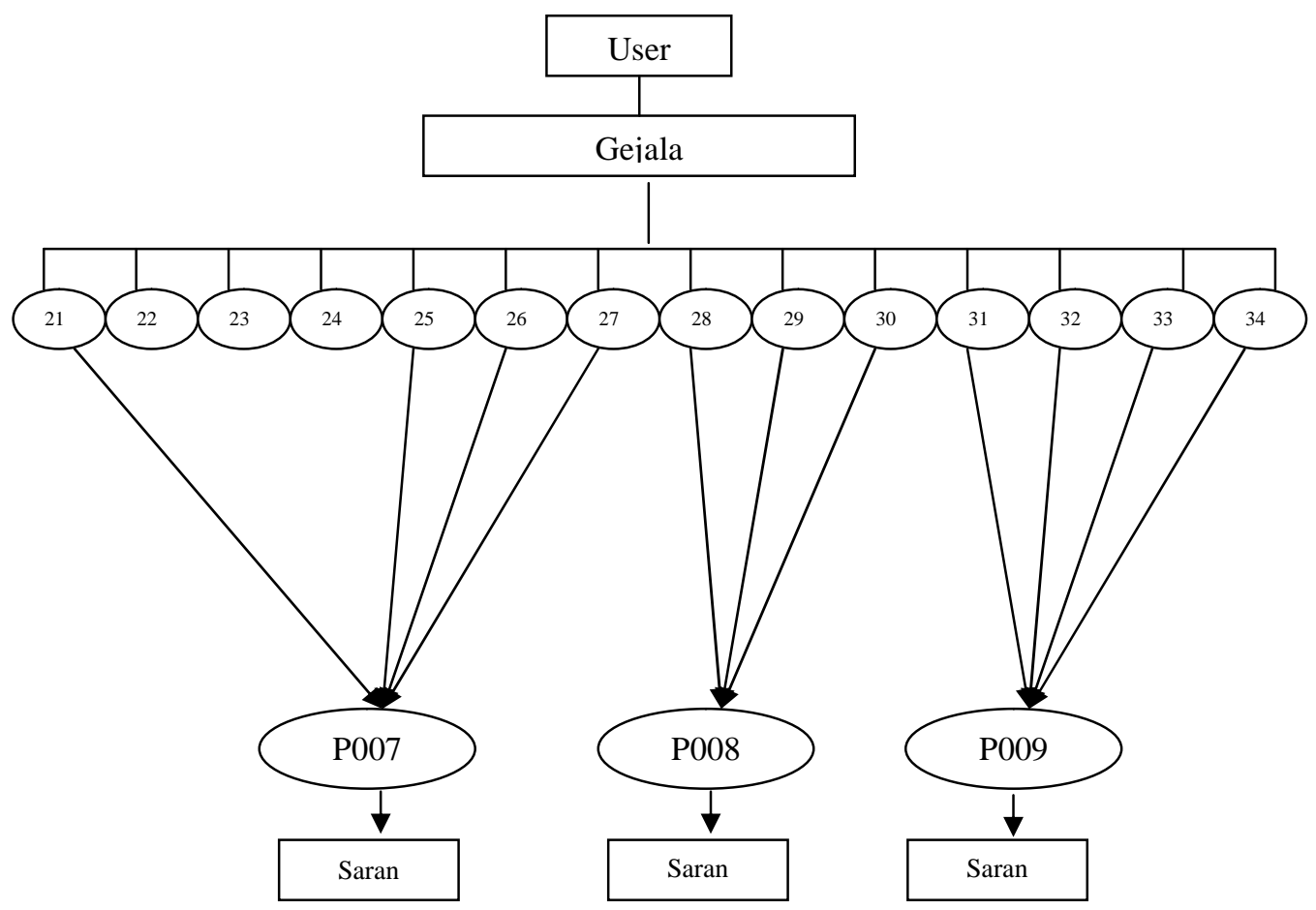

Kaidah Aturan Produksi

Gambar 7. Lanjutan Pohon Keputusan

Kaidah produksi merupakan hasil konversi dari pohon keputusan. Dengan kaidah produksi ini pengetahuan menjadi semakin mudah untuk diorganisasikan dan memudahkan dalam perancangan knowledge base.

Dengan kaidah produksi IF-THEN, mesin inferensi dengan mudah mendapatkan kesimpulan dari fakta-fakta yang diketahui dengan cara penelusuran fakta-fakta yang diketahui pada bagian setelah IF dari kalimat aturan tersebut.

Adapun kaidah yang dibentuk berdasarkan gambar diatas adalah seperti pada Tabel 2 dan 3 dibawah ini :

Tabel 2. Tabel kaidah produksi aturan

\begin{tabular}{|l|l|}
\hline Aturan & Gejala \\
\hline R1 & $\begin{array}{l}\text { IF batuk berdahak kadang disertai darah AND dahaknya disertai bau busuk AND } \\
\text { dada nyeri ketika bernafas AND sering merasa kelalahan AND nafsu makan } \\
\text { berkurang AND berat badan turun secara perlahan THEN Abses Paru }\end{array}$ \\
\hline R2 & $\begin{array}{l}\text { IF batuk dahak kadang disertai darah AND sesak nafas berat AND mengi/bengek } \\
\text { AND demam THEN Aspergilosis Bronkopulmoner }\end{array}$ \\
\hline R3 & $\begin{array}{l}\text { IF sesak nafas ringan AND mengalami gangguan pernafasan AND nyeri dada } \\
\text { AND batuk kering THEN Atelektasis }\end{array}$ \\
\hline R4 & $\begin{array}{l}\text { IF sesak nafas ringan AND berat badan turun secara drastis AND badan terasa } \\
\text { lemas THEN Berilliosis }\end{array}$ \\
\hline R5 & $\begin{array}{l}\text { IF sesak nafas ringan AND ada riwayat pemaparan debu AND kondisi memburuk } \\
\text { jika berada ditempat berdebu AND kondisi membaik jika jauh dari tempat berdebu } \\
\text { AND dada terasa sesak AND batuk pendek-pendek THEN Bissinosis }\end{array}$ \\
\hline R6 & $\begin{array}{l}\text { IF pernafasan cepat AND denyut jantung cepat AND badan berkeringat AND } \\
\text { merasa pusing-pusing THEN Emboli Paru }\end{array}$ \\
\hline R7 & $\begin{array}{l}\text { IF pernafasan cepat AND batuk berdahak kadang disertai lendir atau nanah AND } \\
\text { kadang merasa mual dan muntah AND badan menggigil THEN Pneumonia }\end{array}$ \\
\hline R8 & $\begin{array}{l}\text { IF volume air seni meningkat AND disertai nyeri tulang AND sering merasa haus } \\
\text { walaupun banyak minum THEN Histiositosis X }\end{array}$ \\
\hline R9 & $\begin{array}{l}\text { IF mudah merasa lelah AND tidak enak badan AND terjadi pendarahan dihidung } \\
\text { AND disertai luka disekitar hidung THEN Granulomatosis Pulmoner }\end{array}$ \\
\hline
\end{tabular}


Tabel 3. Tabel kaidah produksi saran

\begin{tabular}{|l|l|}
\hline Aturan & Saran \\
\hline Saran 1 & IF P001 THEN S001 AND S002 AND S003 AND S004 \\
\hline Saran 2 & IF P002 THEN S001 AND S005 AND S006 \\
\hline Saran 3 & IF P003 THEN S001 AND S002 AND S007 \\
\hline Saran 4 & IF P004 THEN S001 AND S008 AND s009 AND S010 \\
\hline Saran 5 & IF P005 THEN S001 AND S002 AND S011 AND S012 \\
\hline Saran 6 & IF P006 THEN S001 AND S002 AND S013 \\
\hline Saran 7 & IF P007 THEN S001 AND S002 AND S004 AND S014 \\
\hline Saran 8 & IF P008 THEN S001 AND S002 AND S015 \\
\hline Saran 9 & IF P009 THEN S001 AND S002 AND S010 AND S016 \\
\hline
\end{tabular}

Aturan saran ini terdiri dari sembilan aturan. Aturan tersebut menghasilkan kesimpulan berupa penyakit yang diperoleh dari fakta-fakta yang ada. Sebagai contoh untuk memperoleh kesimpulan jenis penyakit Abses paru, pada awal penelusuran yang dimulai dengan aturan R1, diketahui batuk berdahak kadang disertai darah AND dahaknya disertai bau busuk AND dada nyeri ketika bernafas AND sering merasa kelalahan AND nafsu makan berkurang AND berat badan turun secara perlahan THEN Abses Paru. Jika Penyakitnya sudah disimpulkan maka dapat pula disimpulkan sarannya.

\section{Diagram Konteks}

Diagram konteks berfungsi untuk memudahkan pemodelan dan fungsi di dalam pengembangan sistem. Ilustrasi diagram konteks sistem dapat dilihat pada gambar 3.13 dibawah ini :

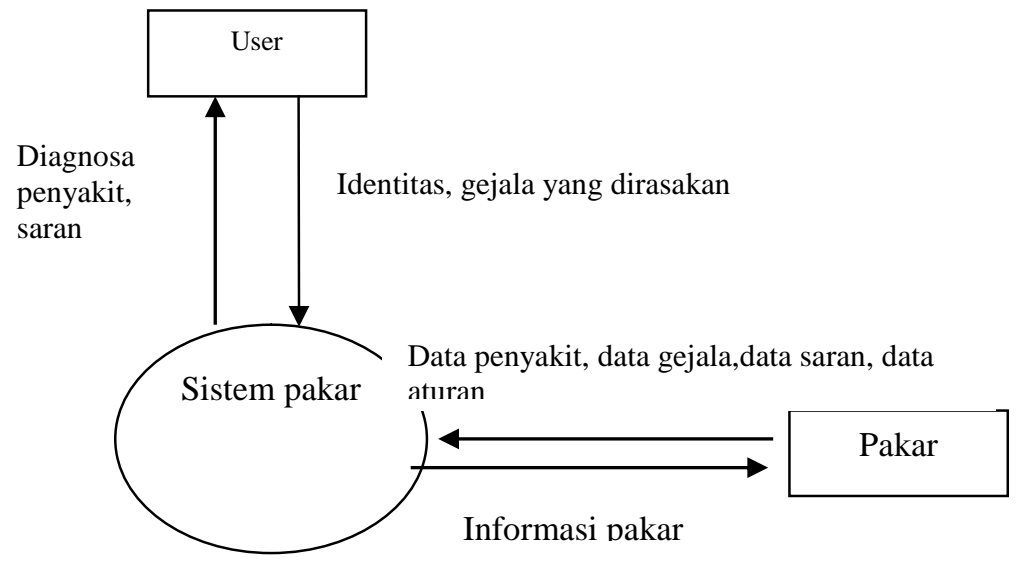

Gambar 8. Diagram Konteks

Diagram konteks di atas memberikan gambaran bahwa sistem berinteraksi dengan dua terminator, yaitu pakar dan User. Tanda panah menunjukkan masukan dan keluaran data. Seorang pakar memasukkan data-data kepakaran ke sistem. Data-data ini nantinya akan digunakan untuk menjawab masukan atau gejala yang diajukan oleh user kepada sistem berupa kesimpulan yang diperlukan. Output yang dihasilkan sistem berupa jawaban dari gejala yang dimasukkan oleh pengguna berupa diagnosa penyakit, disertai saran. 
4. HASIL DAN PEMBAHASAN

Hasil dan pembahasan dari program aplikasi sistem pakar untuk mendiagnosa penyakit infeksi TBC paru ini terdiri dari beberapa form yang memiliki fungsi sendir-sendiri. Form-form tersebut akan muncul sesuai dengan menu yang dipilih.

\section{Menu Utama}

Pada form ini merupakan tampilan awal Sistem Pakar untuk mendiagnosa penyakit infeksi TBC Paru yang terdiri dari dua menu, yaitu menu pakar dan menu user. Hasil dari menu utama dapat dilihat pada Gambar 9.

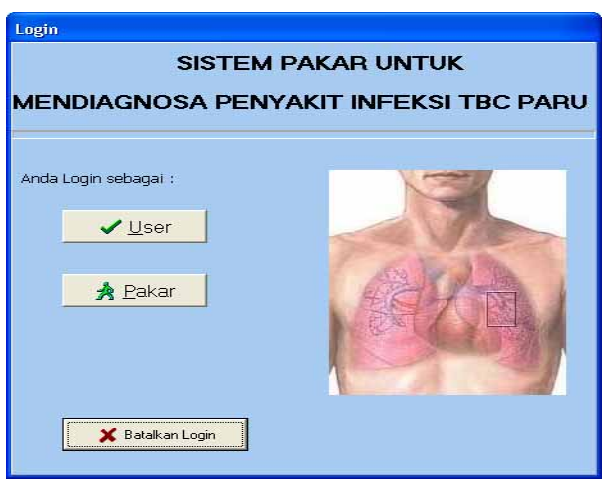

Gambar 9. Menu utama

\section{Menu Pakar}

Menu utama diatas memiliki dua buah tombol yaitu tombol menu User dan Pakar. Menu pada Gambar 10 berikut ini adalah menu dari tombol Pakar. Jika dipilih maka secara otomatis sistem akan menampilkan menu login pakar.

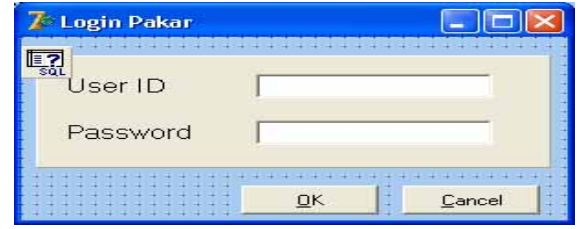

Gambar 10. Menu Login Pakar

Setelah pakar memasukkan user id dan password dan memilih tombol OK maka menu basis pengetahuan akan aktif. Selanjutnya pakar dapat memanipulasi data-data tentang penyakit.

\section{Menu Basis Pengetahuan}

Langkah berikut setelah pakar berhasil login ke dalam sistem adalah menu basis pengetahuan. Dalam menu basis pengetahuan ini, pakar dapat memanipulasi, menambah, menghapus dan memperbarui pengetahuan dan aturan-aturan yang dimilikinya. Tampilan menu ini dapat dilihat pada Gambar 11.

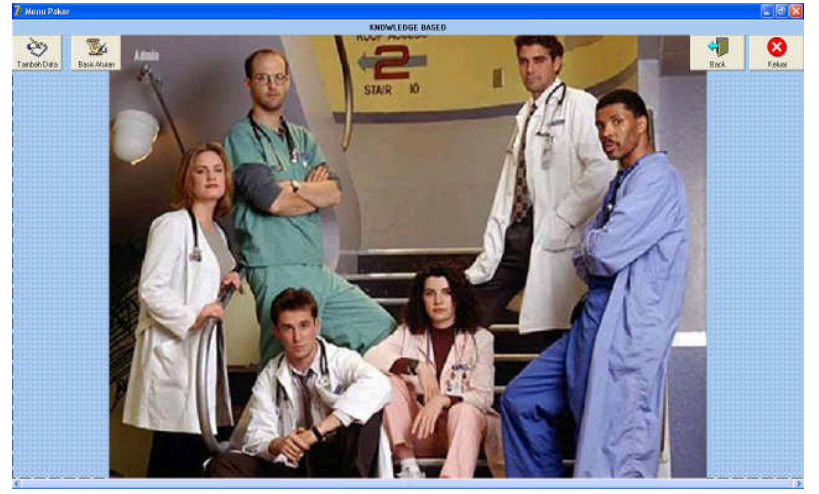

Gambar 11. Menu Basis Pengetahuan 


\section{Menu User}

Menu user ini sekilas memiliki kemiripan interface dengan menu basis pengetahuan akan tetapi fungsinya berbeda. Menu user ini digunakan oleh pengguna untuk berkonsultasi dengan sistem terkait penyakit yang dideritanya. Tampilan menu user disajikan dalam Gambar 12.

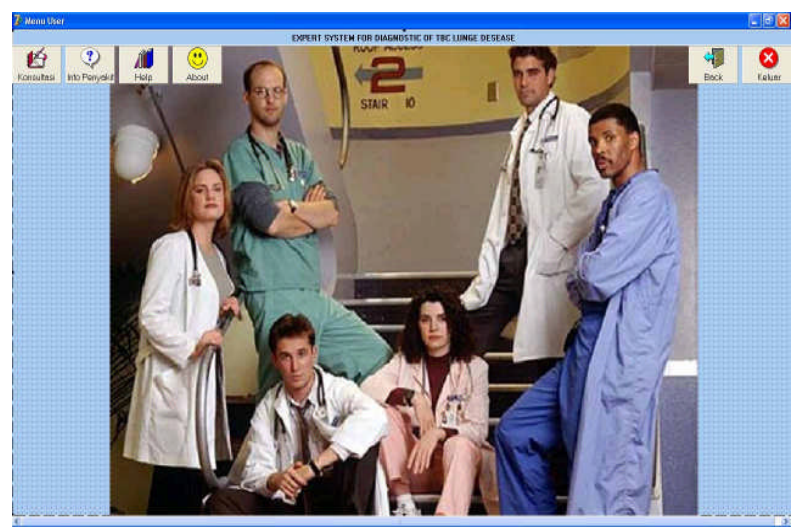

\section{Menu Konsultasi}

Gambar 12. Menu User

Menu konsultasi merupakan menu pokok dalam sebuah sistem pakar. Menu konsultasi dipakai oleh user untuk berkonsultasi dengan sistem pakar. Pengguna dapat memasukkan gejalagejala yang diberikan oleh sistem dengan menjawab Ya atau Tidak. Setiap gejala yang dipilih oleh user akan disimpan dan direkam dalam working memory. Untuk mendapatkan hasil yang optimal, semua pertanyaan wajib dijawab oleh user. Tampilan menu konsultasi dapat dilihat pada Gambar 13.

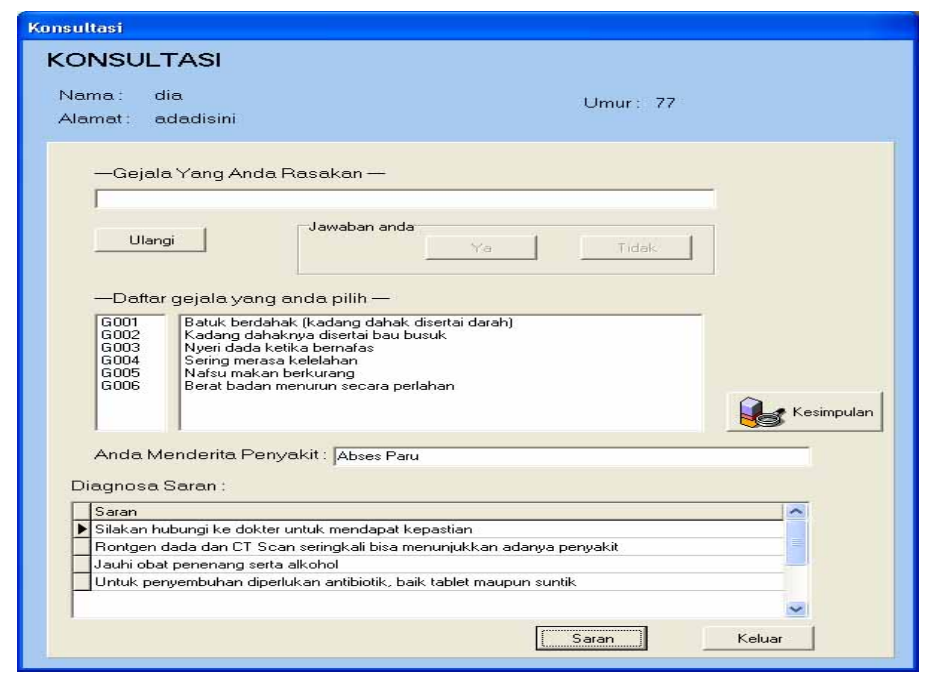

Gambar 13. Menu Konsultasi

\section{KESIMPULAN}

Hasil penelitian ini dapat disimpulkan bahwa :

1. Pembuatan sistem pakar untuk mendiagosa penyakit infeksi TBC paru sudah berhasil sesuai dengan rancangan.

2. Sistem pakar yang dibuat sudah dapat menghasilkan solusi yang dibutuhkan sesuai dengan gejala yang diinputkan user.

3. Basis pengetahuan dapat direpresentasikan dengan kaidah produksi berdasarkan nama penyakit, gejala-gejala serta saran pengobatan.

4. Sistem pakar yang dibuat dapat digunakan untuk menambah dan meng-update data gejala, data penyakit dan data saran berdasarkan gejala utama. 


\section{DAFTAR PUSTAKA}

Asiyah, S. (2005). Sistem Pakar Diagnosa Penyakit Gigi. Skripsi, Fakultas MIPA :Universitas Gadjah Mada.

Beni, S. (2006). Sistem Pakar Untuk Mendiagnosa Gangguan Sistem Pernafasan Pada Hewan Ternak. Skirpsi, Fakultas MIPA:Universitas Gadjah Mada.

Dian, N. (2006). Sistem Pakar Penentuan Bibit Tebu Dari Ketersediaan Lahan Perkebunan Rayon Bantul Pabrik Gula Madukismo Yogyakarta. Skripsi, Fakultas MIPA : Universitas Gadjah Mada.

Giarratano, J., Riley, G., (2004). Expert System Principles and Programming, Carlson, Second Edition, PWS Publishing Company, Boston.

Hisyam, B. (2005) Literatur Perkuliahan Ilmu Penyakit Dalam: Tuberkulosis Paru, Universitas Muhammadiyah Yogyakarta.

Kusumadewi, S.(2003). Artificial Intelligent Teknik dan Aplikasinya, Graha Ilmu, Yogyakarta.

Turban, E., 2005, Decision Support System and Expert System, Prantice Hall International Inc, New Jersey. 